\title{
Penyuluhan Penggunaan Asap Cair dan Kemasan Vakum pada UMKM Makanan Berbasis Hasil Laut di Tambaklorok, Semarang Utara
}

\author{
Meiliana* \\ Christiana Retnaningsih \\ Berta Bekti Retnawati \\ *Program Studi Teknologi Pangan, Universitas Katolik Soegijapranata; meiliana@unika.ac.id \\ Program Studi Manajemen, Universitas Katolik Soegijapranata
}

\author{
A R T I C L E I N F O \\ Article history: \\ Received 12 Juli 2020 \\ Revised 30 Juli 2020 \\ Accepted 25 Agustus 2020
}

Key words:

seafood, liquid smoke,vacuum packaging

\begin{abstract}
A B S T R A C T
Tambaklorok area in North Semarang has many Micro, Small, $\mathcal{E}$ Medium Enterprises (MSMEs) which produce seafood products, such as smoked fish, shrimp paste, fish or shrimp nugget, and fried anchovies. Most of the MSMEs in Tambaklorok still use traditional food technology for food processing and packaging, such as fish curing using smoke and simple packaging using plastic bags. The exposure of cooking smoke used for fish curing might impair the lung and respiratory system of the workers. Therefore, producers might utilize liquid smoke as an alternative smoked fish processing. Besides, in order to increase the production scale, producers might use vacuum packaging to extend the shelf life of food. The producers' lack of knowledge regarding those processing and packaging alternatives might prevent the growth of their business ventures. For this reason, it is necessary to provide community outreach and counselling session to increase the knowledge and awareness of the producers on the processing and packaging alternatives. The participants welcomed such program and showed interests in applying those alternatives on their products.
\end{abstract}

\section{A B S T R A K}

Daerah Tambaklorok di Semarang Utara memiliki banyak Usaha Mikro, Kecil, dan Menengah (UMKM) yang memproduksi produk olahan hasil laut, seperti ikan asap, terasi, nugget ikan atau udang, dan rebon. Sebagian besar UMKM di Tambaklorok masih menggunakan metode pengolahan pangan tradisional dan pengemasan sederhana. Paparan asap pada pengolahan ikan asap memiliki efek negative terhadap kesehatan paru-paru pengolah makanan. Asap cair dapat digunakan sebagai alternatif pada pengolahan ikan asap. Selain itu, untuk meningkatkan skala produksi, pengolah makanan dapat memanfaatkan teknologi pengemasan vakum untuk memperpanjang umur simpan produk pangan. Pengetahuan pengolah pangan yang kurang akan afternatif pengolahan dan pengemasan pangan dapat menghambat kemajuan usaha pangan mereka. Program pengabdian masyarakat 
dan sesi penyuluhan diharapakan dapat meningkatkan pengetahuan dan kesadaran pengolah makanan mengenai teknologi alternatif tersebut. Peserta program menyambut dengan baik kegiatan ini dan menunjukkan ketertarikan untuk mulai menggunakan teknologi alternatif yang disarankan.

\section{PENDAHULUAN}

Kebanyakan anggota komunitas ibu rumah tangga di daerah Tambaklorok, Semarang Utara mengolah hasil laut menjadi produk hasil laut seperti ikan asap, ikan asin, terasi, dan rebon. Produk-produk tersebut diolah secara sederhana dengan pengetahuan teknologi pangan yang minim dan didapatkan secara turun temurun. Observasi yang dilakukan tim program pengabdian kepada masyarakat (PKM) di lapangan menunjukkan kurangnya kualitas keamanan pangan produk-produk tersebut ditinjau dari higienitas pengolahan dan pengemasan produk.

Ikan asap adalah salah satu produk hasil laut khas daerah Semarang Utara. Ikan asap yang dibuat dari ikan manyung, ikan sembilang, dan ikan pari memiliki cita rasa yang khas dan lezat. Ikan asap tersebut dapat diolah lagi menjadi sambal dan dapat dimasak dengan bahan lain, seperti terong, tempe, dan santan. Pengasapan adalah salah satu metode yang dipakai untuk mengawetkan produk pangan yang mengandung protein tinggi seperti ikan, daging, keju (Suroso et al, 2018; Paputungan et al, 2015). Namun, tujuan ini bergeser untuk menghasilkan produk dengan flavour yang khas (Prasetyo el al, 2015).

Proses produksi ikan asap di daerah Tambaklorok menggunakan batok kelapa atau kayu di area terbuka (Gambar 1). Proses ini tidak aman bagi pengolah ikan asap karena asap yang dihasilkan langsung terhirup oleh pengolah ikan asap. Asap tersebut mengandung senyawa benzopirene yang berpotensi sebagai bahan karsinogenik. Selain itu, metode pengasapan tersebut menghasilkan produk dengan kualitas yang kurang konsisten dan menjadi sumber pencemaran udara di lingkungan sekitar produksi ikan asap.

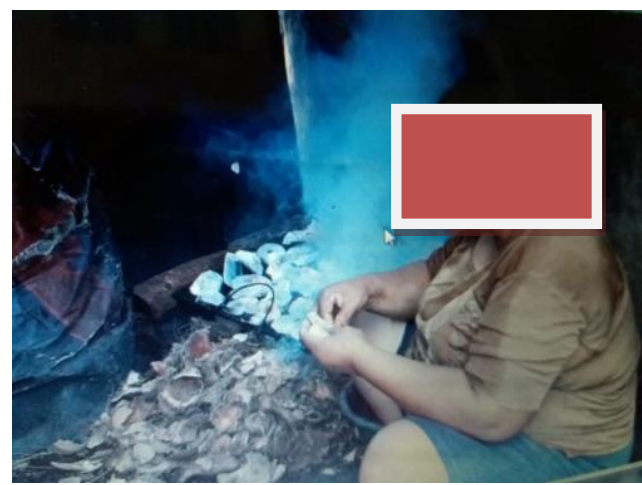

Gambar 1. Proses pengasapan ikan

Asap cair adalah alternatif pengolahan ikan asap yang dikembangkan untuk mengatasi kekurangan-kekurangan tersebut (Ayudiarti et al, 2010; Suroso et al, 2018). Pengolahan ikan asap menggunakan asap cair mudah untuk diterapkan, menghasilkan produk ikan asap dengan flavour yang beragam, mengeliminasi senyawa karsinogenik, 
serta meningkatkan umur simpan produk.

Selain proses pengolahan, pengemasan juga merupakan proses yang penting pada teknologi pangan. Kemasan utama produk pangan bertujuan untuk mencegah atau mengurangi kerusakan, melindungi produk dari bahaya pencemaran, dan meningkatkan nilai ekonomi produk (Potter \& Hotchkiss, 1996). Pengemasan yang biasa dilakukan untuk mengemas produk ikan atau makanan beku adalah polypropylene, polyethylene, dan nylon/polyamide guna memperpanjang umur simpan produk (Astawan et al., 2015; Harris \& Fadli, 2014). Hasil observasi di lapangan menunjukkan bahwa pengetahuan produsen di daerah Tambaklorok mengenai alternative pengolahan pengasapan dan kemasan produk masih kurang. Produk hasil laut di daerah Tambaklorok menggunakan proses pengasapan yang berisiko mengganggu kesehatan pengolah. Selain itu, pengemasan yang digunakan juga sangat sederhana dan belum mempertimbangkan umur simpan produk yang panjang untuk meningkatkan omzet penjualan.

\section{METODE PELAKSANAAN}

Berdasarkan masalah yang ditemui di lapangan, kegiatan penyuluhan dipilih sebagai metode untuk meningkatkan pengetahuan mitra Usaha Mikro, Kecil, dan Menengah (UMKM) makanan berbasis hasil laut di daerah Tambaklorok mengenai pangan. Kegiatan PKM dibagi dalam tiga tahap yaitu tahap persiapan, tahap pelaksanaan dan tahap evaluasi.

Tahap persiapan kegiatan ini dilakukan dengan melakukan kunjungan lapangan dan Focus Group Discussion (FGD). Kunjungan lapangan dilakukan oleh dua orang dosen dan empat orang mahasiswa untuk mengetahui kondisi pengolahan dan pengemasan produk hasil laut UMKM di daerah Tambaklorok. Setelah analisis situasi didapatkan, tim program pengabdian kepada masyarakat (PKM) melakukan FGD bersama dengan dua mitra UMKM dan Lembaga Pendamping Usaha Buruh Tani dan Nelayan (LPUBTN) sebagai pendamping pelaku usaha pangan di daerah Tambaklorok. Melalui FGD ini, tim PKM menggali kebutuhan dan harapan dari mitra UMKM mengenai usaha produk hasil laut mereka. Kebutuhan dan harapan ini menjadi dasar pelaksanaan penyuluhan tim PKM yang bertujuan untuk meningkatkan pengetahuan mitra UMKM mengenai pengolahan ikan asap yang aman dan pengemasan produk hasil laut yang efektif.

Tahap pelaksanaan kegiatan penyuluhan dilaksanakan dengan metode ceramah. Tim PKM menjelaskan penggunaan asap cair dalam pengolahan ikan asap untuk mengurangi paparan senyawa karsinogenik dan kemasan vakum untuk meningkatkan kualitas dan umur simpan produk hasil laut. Ceramah ini diikuti oleh dua mitra UMKM beserta pada pelaku UMKM lainnya di daerah Tambaklorok. Ceramah dilanjutkan dengan diskusi dan tanya jawab. Tahap evaluasi dilakukan untuk mengamati peningkatan pengetahuan dan kesadaran dua mitra UMKM serta perbaikan proses pengolahan ikan asap maupun pengemasan produk hasil laut. 


\section{HASIL DAN PEMBAHASAN}

Kunjungan lapangan dilakukan tim PKM dengan dan didampingi oleh ketua RW (Gambar 2). Hasil observasi di tempat produksi ikan asap milik Ibu Sukarti menunjukkan masih perlu dilakukan perbaikan proses pengolahan yang tidak berefek negative terhadap kesehatan pengolah ikan asap. Pengolah ikan asap tidak menggunakan masker selama proses pengasapan. Proses pengasapan ikan menghasilkan senyawa Polycyclic Aromatic Hydrocarbons (PAHs) yang memiliki potensi karsinogenik. Selain itu, pengolah ikan asap juga tidak memakai apron yang berguna untuk melindungi pakaiannya dan mencegah kontaminasi silang. Meski demikian, pengolah ikan asap sudah berusaha menjaga higienitas produk dengan menggunakan tutup kepala dan menjaga kuku tangan selalu terpotong pendek. Selain ikan asap, produk hasil laut yang dihasilkan di daerah Tambaklorok adalah nugget udang yang dikemas secara sederhana menggunakan plastik (Gambar 3) yang belum diketahui jenisnya oleh pelaku usaha.

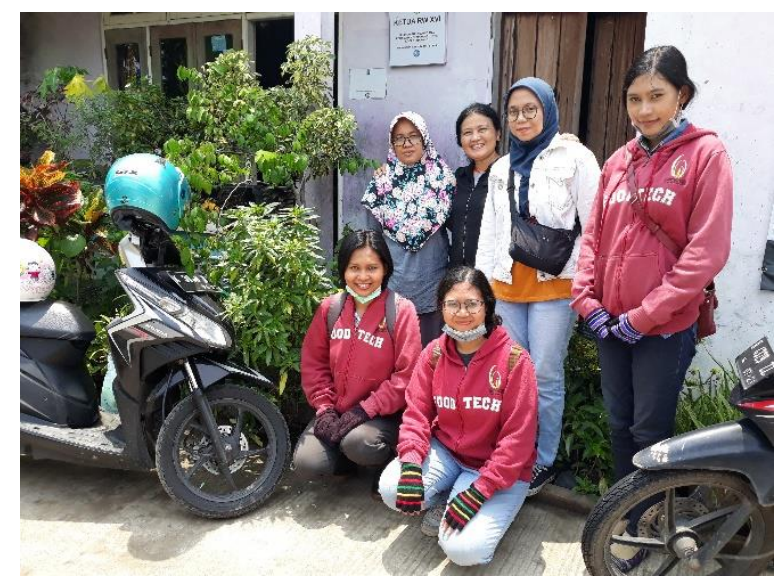

Gambar 2. Kunjungan lapangan tim PKM

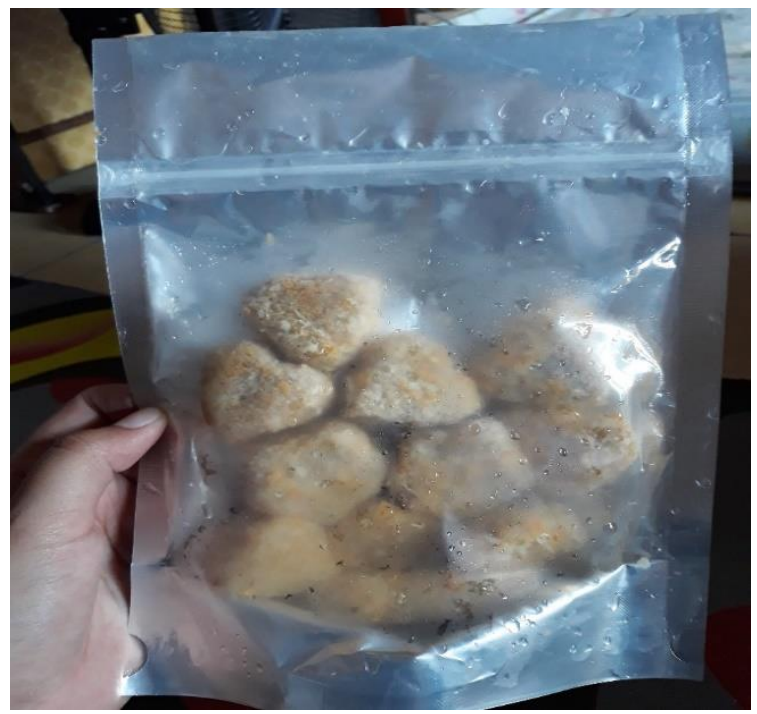

Gambar 3. Kemasan produk nugget udang 
Kegiatan kunjungan lapangan dilanjutkan dengan $F G D$ mitra UMKM makanan berbasis hasil laut (Gambar 4). Pada kegiatan tersebut, hadir sekretaris Kelompok Usaha Bersama (KUB) Minakarya yaitu Ibu Sittatun dan Lembaga Pendamping Usaha Buruh Tani dan Nelayan (LPUBTN) sebagai pendamping mitra yang sudah lama beraktivitas mendampingi banyak UMKM makanan dan lainnya di daerah Tambaklorok. Tim PKM melibatkan LPUBTN untuk meningkatkan peluang keberlanjutan program. LPUBTN diharapkan dapat terus mendampingi mitra UMKM setelah kegiatan pengabdian ini berakhir. Dari kegiatan $F G D$ tersebut, didapatkan informasi permasalahan yang ada di lapangan. Masalah-masalah tersebut adalah kurangnya pengetahuan mengenai kualitas bahan baku, proses produksi yang tidak konsisten akibat ketersediaan bahan baku, keterbatasan sarana produksi, kurangnya pengetahuan dan kesadaran terhadap keamanan pangan dan kesehatan pelaku usaha, dan belum ada atau kurangnya kualitas kemasan produk.

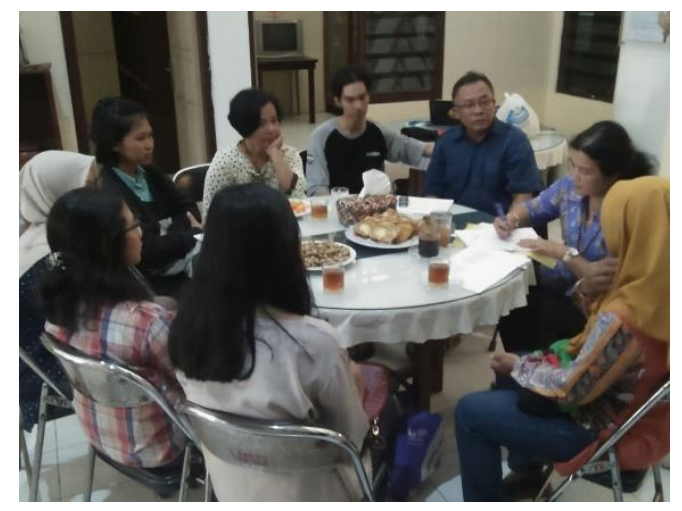

Gambar 4. Diskusi bersama Mitra dan Pendamping UMKM Produk Pangan berbasis Hasil Laut

Tim PKM menyusun perencanaan penyuluhan berdasarkan kebutuhan mitra UMKM makanan berbasis hasil laut di daerah Tambaklorok. Dari beberapa topic penyuluhan, penyuluhan mengenai penggunaan asap cair (Gambar 5) dan kemasan vakum (Gambar 6) dilakukan dengan tujuan meningkatkan pengetahuan mitra UMKM mengenai alternative pengolahan ikan asap yang lebih aman bagi kesehatan pengolah ikan asap dan pengemasan yang cocok untuk produk hasil laut guna meningkatkan umur simpan dan nilai jual produk. 


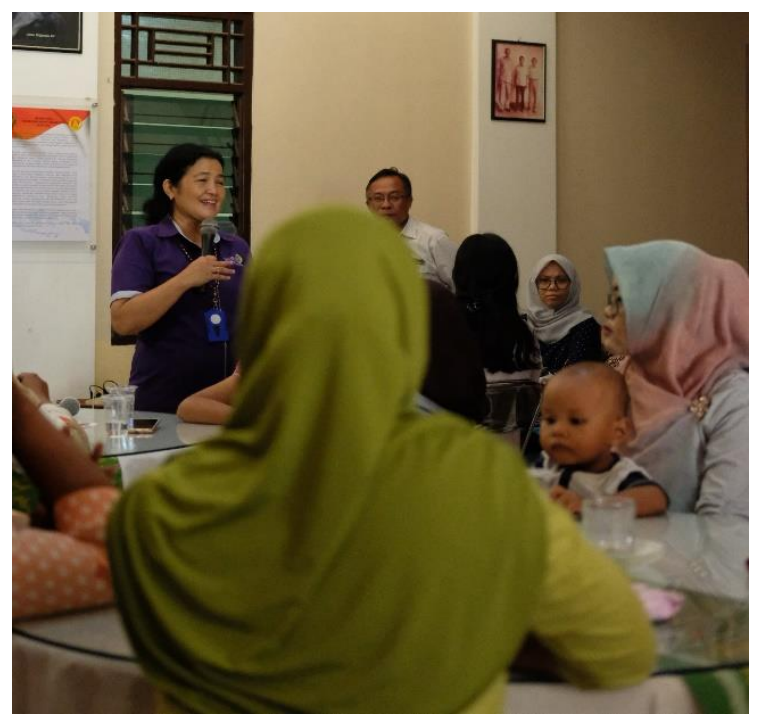

Gambar 5. Suasana Kegiatan Penyuluhan Penggunaan Asap Cair dan Keamanan Pangan pada UMKM Makanan berbasis Hasil Laut

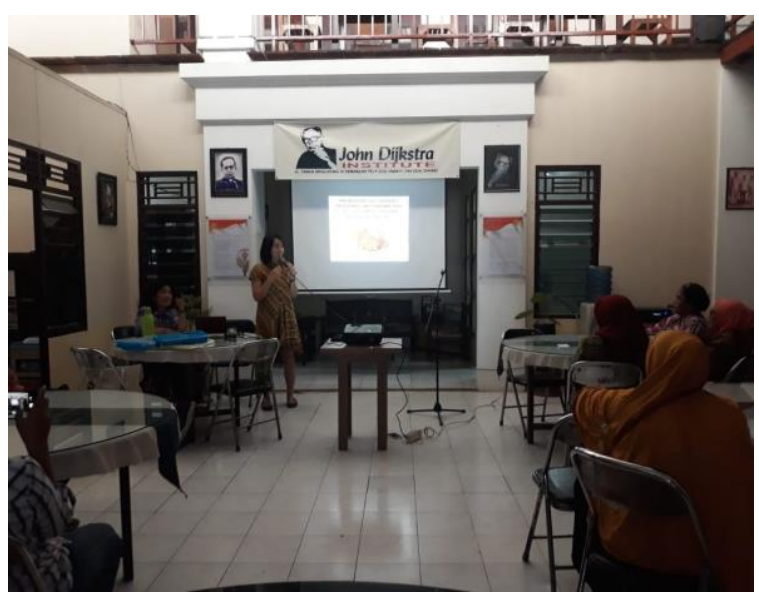

Gambar 6. Suasana Kegiatan Penyuluhan Mutu dan Pengemasan Produk Pangan Hasil Laut

Kegiatan penyuluhan tersebut dilanjutkan dengan kegiatan monitoring dan evaluasi. Monitoring dan evaluasi dilakukan dengan cara observasi saat kunjungan lapangan ke lokasi usaha mitra. Mitra pengolah ikan asap (Ibu Sukarti) menyampaikan memahami kelebihan penggunaan asap cair dibandingkan metode pengasapan tradisional. Namun, Ibu Sukarti sebagai pelaku usaha ikan asap menyatakan bahwa banyak konsumen kurang menyukai flavor dari asap cair. Hal tersebut menjadi masukan bagi para akademisi untuk melakukan penelitian tentang konsentrasi dan jenis asap cair yang tepat untuk menghasilkan produk ikan asap dengan flavor serupa. Hasil monitoring dan evaluasi menunjukkan ada peningkatan pengetahuan dan kesadaran dari mitra pelaku usaha ikan asap. Hal ini terlihat dari peningkatan kualitas alat pengasapan. Ibu Sukarti telah membuat cerobong tempat pengasapan ikan sederhana yang dapat mengurangi paparan asap ke pengolah ikan asap (Gambar 7 dan 8). 


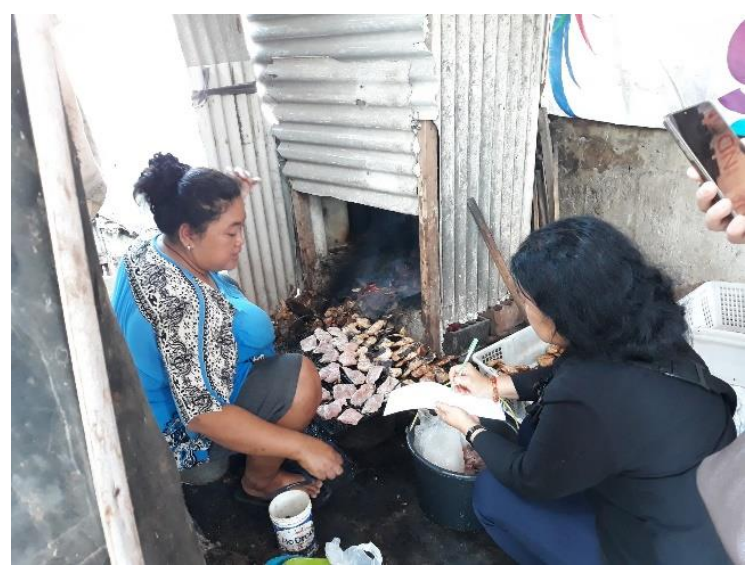

Gambar 7. Tempat pengolahan ikan asap baru

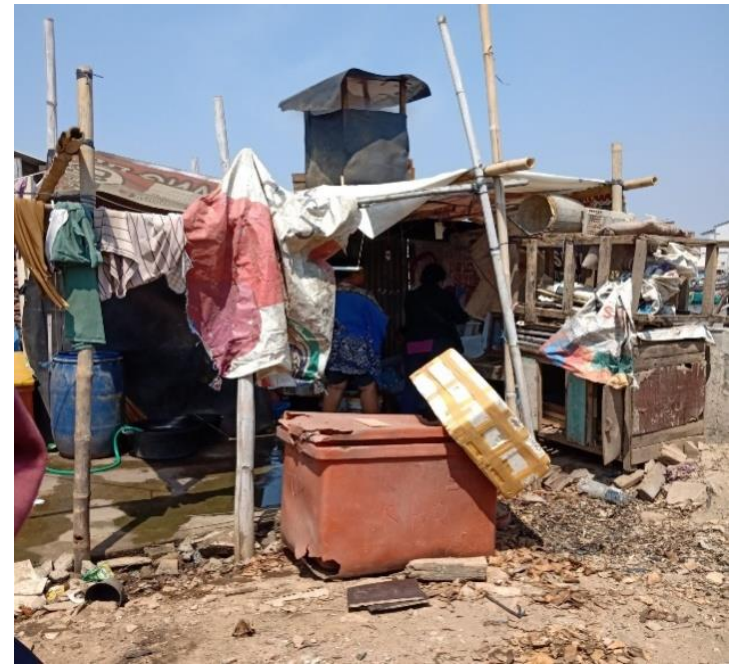

Gambar 8. Cerobong asap dari tempat pengasapan mitra (Ibu Sukarti)

Kunjungan untuk monitoring dan evaluasi juga dilakukan pada mitra UMKM pengolah nugget udang, Ibu Sittatun. Wawancara saat kunjungan menunjukkan ada peningkatan pengetahuan dan kesadaran dari mitra mengenai penggunaan kemasan plastik untuk produk makanan. Pelaku usaha mengerti jenis-jenis plastik yang ada di pasaran dan pentingnya penggunaan plastic food grade untuk mengemas produk pangan. Saat kunjungan, tim PKM juga membawa contoh jenis kemasan plastic nilon dengan vakum dan non-vakum (Gambar 9 dan 10), sehingga mitra mengerti perbedaan bahan pengemas dan bentuk kemasan vakum dan non-vakum. 


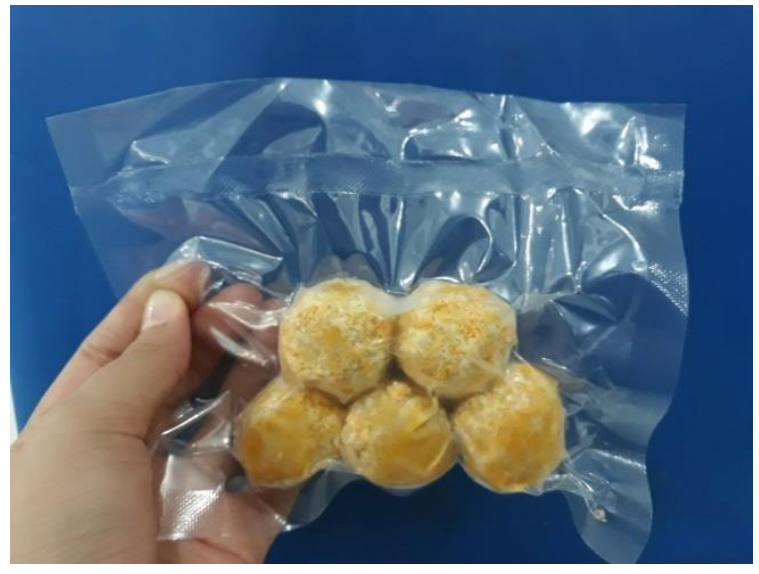

Gambar 91. Nugget udang dengan kemasan vakum

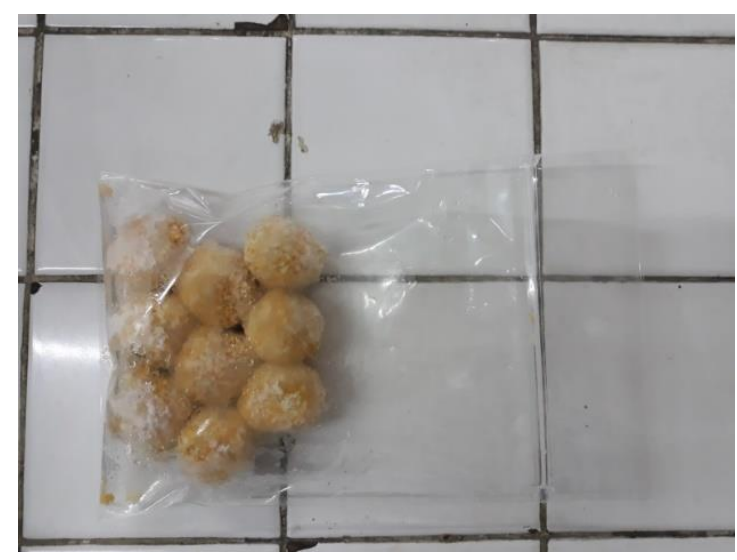

Gambar 10. Nugget udang dengan kemasan non-vakum

\section{SIMPULAN}

Program pengabdian masyarakat meliputi kegiatan penyuluhan mengenai penggunaan asap cair dan pengemasan vakum ini dapat meningkatkan pengetahuan dan kesadaran mitra UMKM mengenai pengolahan dan pengemasan produk pangan hasil laut yang aman. Pengolahan ikan asap selama ini menggunakan metode tradisional sehingga ikan asap memiliki efek negative terhadap kesehatan paru-paru pengolah makanan. Untuk itu perlu dilakukan pengolahan yang lebih maksimal dengan menggunakan asap cair sebagai alternatif pada pengolahan ikan asap.

Untuk meningkatkan skala produksi, pengolah makanan dapat memanfaatkan teknologi pengemasan vakum untuk memperpanjang umur simpan produk pangan. Masyarakat lebih memahami pengetahuan sebagai afternatif pengolahan dan pengemasan pangan dapat menghambat kemajuan usaha pangan mereka. Program pengabdian masyarakat dan sesi penyuluhan diharapkan dapat meningkatkan pengetahuan dan kesadaran pengolah makanan mengenai teknologi alternatif tersebut. Peserta menyambut baik kegiatan tersebut dan menunjukkan ketertarikan untuk mulai menggunakan teknologi alternatif yang disarankan. 


\section{UCAPAN TERIMA KASIH}

Terimakasih kepada RISTEK DIKTI Th. Anggaran 2019 (No. SK: 010/L6/AK/SP2H/PPM/2019) yang telah mendanai kegiatan pengabdian kepada UMKM makanan di Tambaklorok melalui Program Kemitraan Masyarakat dan LPPM Universitas Katolik Soegijapranata yang telah mendukung dan memfasilitasi kegiatan pengabdian ini.

\section{DAFTAR PUSTAKA}

Astawan, M., Nurwitri, C. C., \&Rochim, D. A. (2015). Kombinasi KemasanVakum dan Penyimpanan Dingin untuk Memperpanjang Umur Simpan Tempe Bacem (Combination of Vacuum Packaging and Cold Storage to Prolong the Shelf Life of Tempe Bacem). Jurnal Pangan, 24(2), 125-134.

Ayudiarti, D, L., \& Sari, R, N. (2010). Asap Cair Dan Aplikasinya Pada Produk Perikanan. Squalen, 5(3), 101-108.

Harris, H., \&Fadli, M. (2014). Penentuan Umur Simpan (Shelf Life) Pundang Seluang (Rasbora sp) Yang Dikemas Menggunakan Vakum Dan Tanpa Vakum. Jurnal Saintek Perikanan, 9(2), 53-62.

Paputungan T S, Wonggo D, \& Damongilala L J. (2015). Kajian Mutu Ikan Cakalang (Katsuwonus Pelamis L.) Asap Utuh Yang Dikemas Vakum Dan Non Vakum Selama Proses Penyimpanan Pada Suhu Ruang. Jurnal Media Teknologi Hasil Perikanan, 3(2).

Potter, N. N., \& Hotchkiss, J. H. (2012). Food science. Springer Science \& Business Media.

Prasetyo, D, Y, B., Darmanto, Y, S., \& Swastawati, F. (2015). Efek Perbedaan Suhu dan Lama Pengasapan terhadap Kualitas Ikan Bandeng (ChanoschanosForsk) Cabut Duri Asap. Jurnal Aplikasi Teknologi Pangan, 4(3).

Suroso, E., Utomo, T, P., Hidayati, S., \&Nuraini, A. (2018). Pengasapan Ikan Kembung Menggunakan Asap Cair Dari Kayu Karet Hasil Redestilasi. Jurnal Pengolahan Hasil Perikanan Indonesia, 21(1). 